\title{
SKIEPIJIMO SAUGUMO VERTINIMAS, DVEJOJIMO SKIEPYTIS DIDËJIMAS
}

\author{
Algimantas Žaltauskas, Pijus Ruokis, Rugilè Dobradziejutė \\ Lietuvos sveikatos mokslu universiteto Medicinos akademija
}

Raktažodžiai: vakcinos, vakcinacijos saugumas, vakcinacijos atidèliojimas.

\begin{abstract}
Santrauka
Vakcinacija yra viena efektyviausių visuomenès sveikatą užtikrinančių priemonių dèl savo saugumo, efektyvumo, prieinamumo bei mažos kainos. Visuomenèje kyla baimių ir abejonių dèl vakcinų saugumo - viena dažniausiai nurodomų yra tariama autizmo ir vakcinavimo sąsaja. Tyrimo tikslas - apžvelgti vakcinų saugumą ir nepasitikejimo jų saugumu priežastis. Šaltinių paieška vykdyta $2021 \mathrm{~m}$. balandžio-gegužès mėnesiais duomenų bazèse PubMed, Cohrane Libray. Buvo naudojami raktiniai žodžiai ir jų deriniai: vaccine hesitancy, vaccine mechanisms, vaccine safety, vaccine adverse efects. Analizei atrinkti straipsniai, kuriuose aprašomi tyrimai ar jų apžvalgos, susijusios su vakcinų saugumo vertinimu, skiepų atidèliojimo priežasčių analize. Tyrimo rezultatai parodé, kad autizmo ir vakcinavimo sąsajų nenustatyta, o socialinių tinklų debatuose apie vakcinas, dominuoja netiksli, neigiama, klaidinanti informacija. Išvados. Vakcinavimas ir autizmo susirgimai neturi tarpusavio ryšio. Vakcinų keliama baimé yra ịsisenejusi ir gaji visuomenejje, nepaisant ją pagrindžiančių įrodymų nebuvimo.
\end{abstract}

\section{Ivadas}

Vakcinacija yra viena efektyviausių visuomenès sveikatą užtikrinančių priemonių dèl savo saugumo, efektyvumo, prieinamumo bei mažos kainos [1]. Ne visos vakcinos gali užtikrinti visišką imunizaciją dèl tam tikrų aspektų, susijusių tiek su vakcinuojamuoju asmeniu, jo amžiumi, bendra būkle, tiek su specifine vakcina, jos dozių skaičiumi [2]. Pirminis tipinis atsakas ị vakciną yra specifinių antikūnų gamyba po reakcijos ị vakcinos antigeną, tačiau skirtingų žmonių reakcijos kokybė gali skirtis. Gali būti skirtingas susidarančių antikūnų kiekis, patvarumas, funkcijos pajègumas, gyvavimo periodas. Ilgalaikị žmogaus imunitetą lemia ląstelinis imuninis atsakas, pakartotinų vakcinų dozių sukeliamos sti- prinamosios reakcijos (ar jų nebuvimas) [3]. Patvaraus imuniteto susidarymui reikalingas adekvatus vakcinos laikymas kontroliuojamoje temperatūroje nuo pagaminimo dienos iki suleidimo, tai vadinama ,šaltaja grandine“ [4]. Vakcinavimo efektyvumas gali priklausyti ir nuo vakcinos vartojimo metodo. Iprastinis metodas - intramuskulinè injekcija, tačiau kai kuriose šalyse plačiai taikoma subkutaninès injekcijos metodika [5]. Besivystančiose šalyse injekcijos pavojingos dèl didelès ŽIV ir kitų sukèlèjų pernešimo rizikos, todèl bandomas ir peroralinis gyvujų vakcinų naudojimas [6].

Tyrimo tikslas - apžvelgti vakcinų saugumą ir nepasitikejjimo jų saugumu priežastis.

\section{Tyrimo medžiaga ir metodai}

Mokslinių šaltinių paieška atlikta duomenų bazèse PubMed, Cohrane Libray. Naudoti raktiniai žodžiai ir jų deriniai: vaccine hesitancy, vaccine mechanisms, vaccine safety, vaccine adverse efects. Literatūros analizei atrinktas 21 straipsnis, atitinkantis tyrimo tikslą. Atlikta tyrimui tinkamų viso teksto laisvai prieinamų mokslinių straipsnių, kuriuose vertinamas vakcinų saugumas, nagrinejjamos skiepų atidèliojimo priežastys, analizè.

\section{Tyrimo rezultatai ir jụ aptarimas}

Vakcinos veikimo mechanizmas. Vakcinų sudètyje yra vienas ar daugiau skirtingų baltyminių imunogenų, kuriuos absorbuoja antigeną pristatančios ląstelès. Šios ląstelès kartu su didžiuoju audinių suderinamumo kompleksu antigeną pristato CD4+ T limfocitams. Šie limfocitai sintezuoja citokinus, kurie aktyvuoja humoralinị ir ląstelinị imunitetą, įskaitant CD8+ T limfocitus, makrofagų stimuliaciją [7]. B limfocitai atpažista vakcinas, kurių sudètyje nèra baltymų. B limfocitai gali diferencijuotis ị plazmocitus, kurie išskiria specifinius antikūnus, saugančius nuo bakterinių susirgimų (pvz.: N. meningitidis). Šis mechanizmas neitraukia T limfocitų [8].

Vakcinų saugumas. Japonijoje standartinis vakcinavimo metodas yra subkutaninè injekcija. Intramuskuliné injekcija apribota dèl XX a. aštuntajame dešimtmetyje 
pasirodžiusių apytiksliai 3700 keturgalvio raumens kontraktūrų atvejų. Kontraktūros išsivystè dèl tuo metu dažnai į raumenis leidžiamų antibiotikų ir antipiretikų. Nė vienas iš 3700 atvejų nebuvo sukeltas vakcinos. Japonijos pediatrų draugija paskelbè, jog ị raumenis leidžiami vaistai (antipiretikai ir antibiotikai) vaikams nèra saugūs. Nors vakcinos nebuvo pripažintos nesaugiomis, intramuskulinių vakcinacijų skaičius ženkliai sumažèjo [5].

Lyginant keturvalentę difterijos, B tipo heamophilus influenzae, inaktyvuoto poliomielito, kokliušo (DTaP + IPV) vakciną, kurią buvo leista skirti intramuskuliariai ir subkutaliai, intramuskulinè injekcija sukèlè mažiau vietinio uždegimo požymių (patinimas, paraudimas,skausmingumas) ir pasiekè vienodą ar geresnị imunogeninị efektą [9].

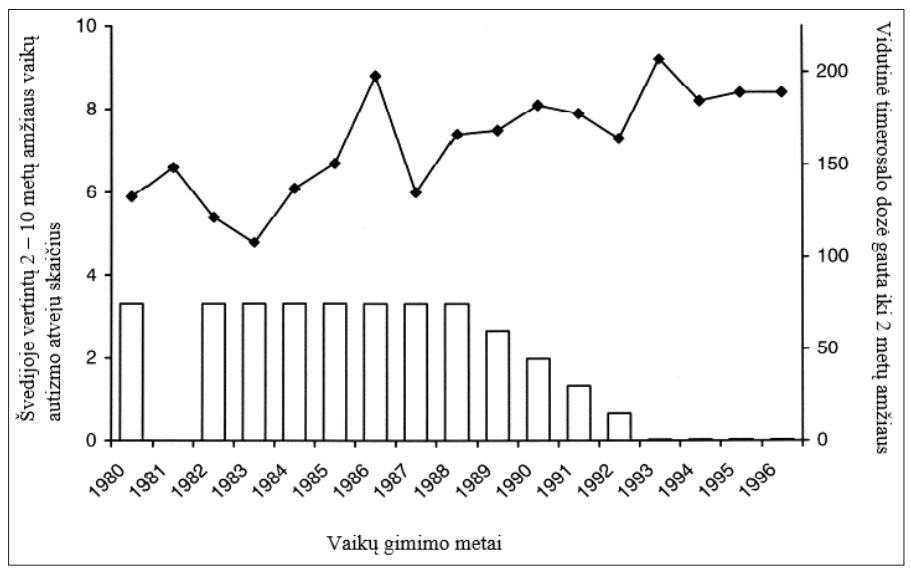

1 pav. Vaikų (2-10 metų) autizmo atvejų Švedijoje skaičius ir vidutinė timerosalo dozè

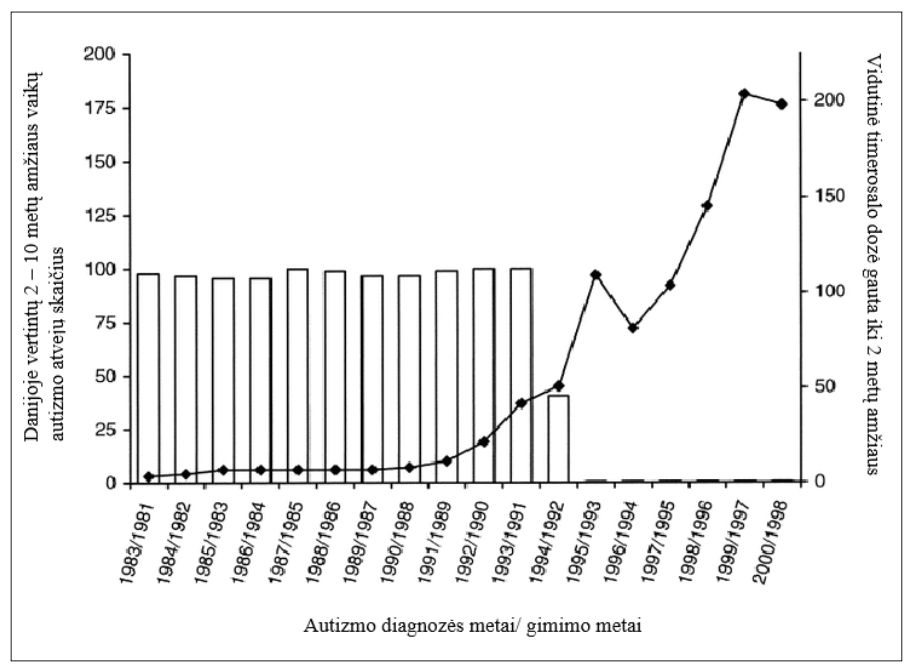

2 pav. Vaikų (2-10 metų) autizmo atvejų Danijoje skaičius ir vidutinė timerosalo dozè
Pastaraisiais metais dèl tariamo vakcinavimo ir autizmo ryšio daugejja vakcinomis stabdomų ligų atvejų [10]. Jungtinèje Karalystėje 1999 m. atliktas tyrimas, kuriame stebèti 498 autizmo diagnozę turintys vaikai, gimę tarp 1979 ir 1992 metų. Tyrimo metu pastebèta, jog vèliau gimę vaikai dažniau sirgo autizmu, tačiau MMR vakcina Jungtinèje Karalysteje buvo pradèta naudoti tik 1987 m., tad jos naudojimas nepakeitè autizmo diagnozių didèjimo tendencijos, nesukèlè staigaus autizmo diagnozių padidèjimo, nebuvo pastebėtas skiepytų ir neskiepytų vaikų, kuriems diagnozuojamas autizmas, amžiaus skirtumas [11]. Tie patys autoriai $2001 \mathrm{~m}$. tęsè minètame tyrime aprašytų pacientų stebėjimą, atsižvelgè ị galimą antrosios dozès poveikị. Šis tyrimas taip pat nerado jokių autizmo apraiškos skirtumų tarp skiepytų ir neskiepytų MMR vakcina vaikų [12].

E. Fombonne, R. Zakarian ir kt. 2006 m. Kanadoje atliko kitą tyrimą, kuriame ieškota MMR vakcinos ir autizmo sąsajų. Prieš tyrimą buvo iškelta autizmo priklausomumo nuo MMR vakcinos hipoteze, tačiau, atlikus tyrimą, kuriame buvo stebėti 27749 vaikai, rezultatai buvo priešingi, autizmo dažnis didejjo mažejjant vakcinavimui MMR vakcina [13].

Timerosalas yra antiseptinis ir priešgrybelinis agentas, turintis gyvsidabrio, plačiai naudotas vakcinų sudètyje, tačiau XXI a. pirmajame dešimtmetyje baigtas naudoti vakcinų gamybai Europoje ir JAV dèl visuomenèje kylančios skiepijimosi baimès. $2003 \mathrm{~m}$. vertintas autizmo pasireiškimas vaikams, skiepytiems vakcinomis su timerosalu. Tyrimo metu mokslininkai analizavo autizmo pasireiškimo vaikams priklausomybę nuo vidutinès gautos timerosalo dozès. İ tyrimą buvo įtraukti Švedijos vaikai, gimę nuo 1980 iki 1996 metų, Danijos vaikai, gimę nuo 1981 iki 1998 metų. Sąsajos tarp autizmo pasireiškimo ir skiepijimo timerosalo turinčiomis vakcinomis nebuvo rasta [14] (1 ir 2 pav.).

Minètame $2006 \mathrm{~m}$. Kanadoje atliktame tyrime buvo vertinta ir timerosalo sąsaja su autizmo pasireiškimu. Ši studija taip pat nerado koreliacijos tarp autizmo ir timerosalo naudojimo [13].

Kita dažnai išreiškiama baimė yra didejjantis gaunamų vakcinų skaičius. Visuomenèje baiminamasi, jog per didelis vakcinų naudojimas gali silpninti imunitetą, sukelti autizmą ar kitą raidos sutrikimą. Nustatyta, kad vakcinuoti ir nevakcinuoti vaikai vienodai dažnai serga ligomis, kurių prevencijai nèra skiepų, todèl negalima teigti, jog vakcinavimas silpnina bendrą imunitetą $[15,16]$. Didelis gaunamų vakcinų kiekis (kaip ir pavienès vakcinos) negali sukelti autizmo, nes autizmo pato- 


\section{4}

fiziologijoje nèra stebèta jokio imuninio mechanizmo [17].

Dvejojimas vakcinuotis. Sunku tiksliai pasakyti, kokia populiacijos dalis dvejoja dèl vakcinavimo saugumo, tačiau pastaraisiais metais stebimas neabejotinas nepasitikejjimo vakcinomis didejjimas [18]. Priežasčiu yra daug, viena svarbiausių laikoma žiniasklaidos platinama dezinformacija. Spaudoje pasirodančios prieš vakcinas nukreiptos antraštès turi neigiamos įtakos vakcinų naudojimui [19]. Dezinformacija greitai sklinda dèl lengvo prieinamumo ir mažos kontrolès internete. Didžioji dalis ją platinančių svetainių negeba teisingai atsakyti ị užduotą klausimą arba i jị neatsako [20]. Vertinant ne tik paieškos rezultatus, bet ir socialiniuose tinkluose randamus debatus apie vakcinas, dominuoja netiksli, neigiama, klaidinanti informacija [21].

\section{Išvados}

1. Vakcinų veikimo mechanizmai yra žinomi, patvirtinti teoriškai ir praktiškai.

2. Vakcinų baimė yra ịsisenèjusi ir gaji visuomenèje, nepaisant ją pagrindžiančių ịrodymų nebuvimo.

3. Priemonès apsaugoti visuomenę nuo tariamai vakcinavimo sukeliamų sveikatos sutrikdymų neturi mokslinio pagrindo ir taikomos visuomenès raminimo tikslais.

4. Vakcinavimas ir susirgimas autizmu neturi tarpusavio ryšio.

5. Dvejones vakcinuotis skatina lengvai platinama dezinformacija internete.

\section{Literatūra}

1. Kohl KS, Bonhoeffer J, Braun MM, Chen RT, Heijbel H, Heininger $\mathrm{U}$, et al. The Brighton collaboration: creating a global standard for case definitions (and guidelines) for adverse events following immunization. Advances in Patient Safety 2019;2:87-102

2. Petraglia TCMB, Farias PMCM, Sá GRSE, Santos EMD, Conceição DAD, Maia MLS. Vaccine failures: assessing yellow fever, measles, varicella, and mumps vaccines. Cad SaudePublica. 2020;36Suppl 2(Suppl 2):e00008520. https://doi.org/10.1590/0102-311x00008520

3. Siegrist CA. Vaccine immunology. In: Plotkin S, Orenstein W, Offit P, Edwards KM, editores. Plotkin's vaccines. 7th ed. Philadelphia: Elsevier 2018:16-34.

4. CDC. Epidemiology and prevention of vaccine-preventable diseases the pink book: course textbook. 13th ed. 2015.

5. Saitoh A, Okabe N. Current issues with the immunization program in Japan: can we fill the "vaccine gap"? Vaccine 2012;30(32):4752-56.

https://doi.org/10.1016/j.vaccine.2012.04.026

6. Justiz Vaillant AA, Grella MJ. Vaccine (Vaccination). StatPearls 2021.

7. Wada H, Shimizu A, Osada T, Tanaka Y, Fukaya S, Sasaki E.
Correction: development of a novel immunoproteasome digestion assay for synthetic long peptide vaccine design. PLoS One 2018;13(10):e0205567.

https://doi.org/10.1371/journal.pone.0205567

8. Falkard B, Charles RC, Matias WR, Mayo-Smith LM, Jerome JG, Offord ES, Xu P, Kováč P, Ryan ET, Qadri F, Franke MF, Ivers LC, Harris JB. Bivalent oral cholera vaccination induces a memory B cell response to the V. cholerae O1-polysaccharide antigen in Haitian adults. PLoSNegl Trop Dis 2019;13(1):e0007057.

https://doi.org/10.1371/journal.pntd.0007057

9. Carlsson R. Studies on a Hib-tetanus toxoid conjugate vaccine: effects of co-administered tetanus toxoid vaccine, of administration route and of combined administration with an inactivated polio vaccine. Vaccine 1999;18(5-6):468-478.

https://doi.org/10.1016/S0264-410X(99)00238-8

10. Taylor LE, Swerdfeger AL, Eslick GD. Vaccines are not associated with autism: an evidence-based meta-analysis of case-control and cohort studies. Vaccine 2014;32(29):3623-9. https://doi.org/10.1016/j.vaccine.2014.04.085

11. Taylor B, Miller E, Farrington CP, et al. Autism and measles, mumps, and rubella vaccine: no epidemiological evidence for a causal association. Lancet 1999;353:2026-9. https://doi.org/10.1016/S0140-6736(99)01239-8

12. Farrington CP, Miller E, Taylor B. MMR and autism: further evidence against a causal association. Vaccine 2001;19:3632-5. https://doi.org/10.1016/S0264-410X(01)00097-4

13. Fombonne E, Zakarian R, Bennett A, Meng L, McLean-Heywood D. Pervasive developmental disorders in Montreal, Quebec, Canada: prevalence and links with immunizations. Pediatrics 2006;118:139-50. https://doi.org/10.1542/peds.2005-2993

14. Stehr-Green P, Tull P, Stellfeld M, Mortenson PB, Simpson D. Autism and thimerosal-containing vaccines: lack of consistent evidence for an association. Am J Prev Med 2003;25(2):101-6. https://doi.org/10.1016/S0749-3797(03)00113-2

15. Davidson M, Letson GW, Ward JI, et al. DTP immunization and susceptibility to infectious diseases: is there a relationship? Am J Dis Child 1991;145:750-4. https://doi.org/10.1001/archpedi.1991.02160070046020

16. Storsaeter J, Olin $\mathrm{P}$, Renemar $\mathrm{B}$, Lagergård $\mathrm{T}$, Norberg R, Romanus V, Tiru M. Mortality and morbidity from invasive bacterial infections during a clinical trial of acellular pertussis vaccines in Sweden. Pediatr Infect Dis J 1988;7(9):637-45. https://doi.org/10.1097/00006454-198809000-00008

17. McCormick MC. Immunization safety review: vaccines and autism. Washington, DC Institute of Medicine 2004.

18. Dubé E, Laberge C, Guay M, Bramadat P, Roy R, Bettinger J. Vaccine hesitancy: an overview. Hum Vaccin Immunother 2013;9(8):1763-73.

https://doi.org/10.4161/hv.24657 
19. Mason BW, Donnelly PD. Impact of a local newspaper campaign on the uptake of the measles mumps and rubella vaccine. $J$ Epidemiol Community Health 2000;54(6):473-4.

https://doi.org/10.1136/jech.54.6.473

20. Scullard P, Peacock C, Davies P. Googling children's health: reliability of medical advice on the internet. Arch Dis Child 2010;95(8):580-2.

https://doi.org/10.1136/adc.2009.168856

21. Keelan J, Pavri V, Balakrishnan R, Wilson K. An analysis of the human papilloma virus vaccine debate on MySpace blogs. Vaccine 2010;28(6):1535-40.

https://doi.org/10.1016/j.vaccine.2009.11.060

\section{EVALUATION OF VACCINE SAFETY, INCREASE IN VACCINE HESITANCY}

\section{A. Žaltauskas, P. Ruokis, R. Dobradziejutė}

Keywords: vaccines, vaccine safety, vaccine hesitancy. Summary

Vaccination is one of the greatest measures in ensuring public health due to its safety, efficacy, and relatively low cost. However, the wide public has had doubt and fears over the safety of vaccines, causing vaccine hesitancy, with one of the most common ones being a supposed relation with autism. We analyzed medical publications for a month between 2021-04-01 and 2021-05-01 using international databases PubMed and Cohrane with the goal of evaluating the safety of vaccines, the causes for growing vaccine hesitancy. Certain keywords and their combinations were used to find specific sources.

Conclusions: 1. The mechanisms of vaccines are known and proven both theoretically and practically. 2 . The fears over the safety of vaccines are a long-standing issue despite the lack of evidence to support it. 3 . The measures being taken to protect the public from supposed vaccine caused health impairments are taken to appease the public's fears rather than being scientifically based. 4. Vaccination and autism are not related or linked. 5. Vaccine hesitancy is being perpetuated by the misinformation that is readily available online.

Correspondence to: algimantaszaltauskas@gmail.com

Gauta 2021-05-17 